a thrombus (Wessler and Reimer, 1960). Daniel et al. (1968) suggested that very high levels of plasma factor IX may be related to the development of puerperal venous thrombosis. It would appear reasonable to avoid the use of therapeutic agents which give rise to excessive or prolonged increases in factor IX levels during the puerperium. If lactation is to be suppressed with oestrogen it is preferable to use the smallest dose that proves effective.

The present study has shown that intramuscular hexoestrol has a theoretical advantage over oral stilboestrol in that the increase in factor IX levels is not so great and is of a shorter duration. With most hexoestrol-treated patients plasma factor IX has reverted to normal by the time they leave hospital.
We are grateful to Dr. W. R. Pitney for instruction in the technique of factor IX estimations and for his advice at all stages, and to Ortho Pharmaceutical Limited for a supply of factor-IXdeficient plasma and for financial assistance with the study.

\section{REFERENCES}

Dacie, J. V., and Lewis, S. M. (1968). Practical Haematology, 4th ed., p. 297. London, Churchill.

Daniel, D. G., Campbell, H., and Turnbull, A. C. (1967). Lancet, 2,

Daniel, D. G., Bloom, A. L., Giddings, J. C., Campbell, H., and Turnbull, A. C. (1968). British Medical fournal, 1, 801.

Hardisty, R. M., and Macpherson, J. C. (1962). Thrombosis et Diathesis Haemorrhagica, 7, 215.

Wessler, S., and Reimer, S. M. (1960). Fournal of Clinical Investigation, $39,262$.

\title{
Transplacental Passage of Fetal Red Cells in Abortion; Increased Incidence after Curettage and Effect of Oxytocic Drugs
}

\author{
J. KATZ,* м.в., в.CH.
}

British Medical fournal, 1969, 4, 84-86

Summary : In a study of early abortions (less than 16week pregnancies) no significant increase in fetomaternal haemorrhage was found in patients having either threatened or incomplete abortions. A statistically significant increase in fetal cells in the maternal circulation, however, occurred after curettage. The administration of oxytocic drugs in conjunction with curettage in cases of incomplete abortion did not increase the incidence of transplacental passage of fetal erythrocytes when compared with curettage alone. Of the 81 patients curetted following abortion four had a feto-maternal haemorrhage of more than $0.2 \mathrm{ml}$. The largest amount of fetal blood found in the maternal circulation was 0.4 to $0.5 \mathrm{ml}$. Preliminary data evaluating the indirect Coombs test and enzyme-treated red cells in Rh-negative post-abortion cases suggest that this amount of blood is not a primary immunizing dose but a "booster" to preformed antibody.

\section{Introduction}

$\mathrm{Rh}$-immunization in pregnancy is regarded today as a preventable condition. At a symposium held in New York in October 1967 it was concluded that Rh-antibody given to an $\mathrm{Rh}$-negative mother within three days of the delivery of an $\mathrm{Rh}-$ positive infant prevented primary immunization (Rosenfield, 1968). Though most significant feto-maternal transfusions occur during or just after labour (Woodrow et al., 1965 ; Zipursky et al., 1963b), it has been shown by Zipursky et al. (1963b) and Cohen and Zuelzer (1964) that there are small fetomaternal transfusions during the early months of normal pregnancies. The early feto-maternal transfusions have prompted Zipursky and Israels (1967) to administer small doses of Rhantibody during the third trimester in $\mathrm{Rh}$-negative pregnancies, to prevent $\mathrm{Rh}$-sensitization during the pregnancy.

Abortion has been incriminated as a mechanism for Rhsensitization (Gellén et al., 1965 ; Matthews and Matthews,

- Senior Haematologist, South African Institute for Medical Research, Jolrannesburg.
1969), and it has been suggested that non-immunized Rh-negative women who abort should receive prophylactic $\mathrm{Rh}$-antibody (British Medical fournal, 1968). These reports, ccupled with the finding that traumatic manipulations in pregnancy, amniocentesis (Zipursky et al., 1963a), caesarean section, and manual removal of the placenta (Zipursky et al., 1963a) are associated with massive feto-maternal haemorrhage, led to the present investigation of feto-maternal haemorrhage in early abortion, and its incidence after curettage, and of the effect of administering oxytocic drugs. Increased passage of feto-maternal red cells after abortion, in sufficient quantity to induce immunization or sensibilization, would necessitate the administration of Rh-antibody to post-abortion, Rh-negative mothers.

\section{Methods}

The technique used to demonstrate fetal cells in the maternal circulation was a modification of the acid-elution method of Kleihauer, Braun, and Betke (1957). The fetal erythrocytes containing haemoglobin $\mathrm{F}$ stain a darker red colour than the maternal erythrocytes. This is an accepted method for enumerating fetal red cells in the maternal circulation (Zipursky et al., 1959; Finn et al., 1961). Duplicate slides of blood smears were examined from all subjects, and two control slides were set up with each batch of slides, one from a normal nonpregnant subject and one from a subject with a known high fetal haemoglobin content (namely, from a young infant's blood or cord blood). With a low-power lens 50 fields-giving an approximate count of 150,000 cells-were counted in each slide. The mean of the two slides was taken as the fetal erythrocyte score. A fetal cell score ${ }^{1}$ of 1 was recorded if one fetal cell was counted in both slides. If a fraction resulted when more than one fetal cell was counted the next highest digit was taken as the fetal score. Five fetal red cells is equivalent to about $0.2 \mathrm{ml}$. of fetal blood in the maternal circulation (Woodrow et al., 1965). To ascertain with certainty the embryonic blood picture, the acid-elution technique of Kleihauer was performed on cord blood of a 12-week fetus 
(Fig. 1). ABO, Rh-blood grouping, indirect Coombs test, and Rh-titre were performed by standard methods (Dacie and Lewis, 1966).

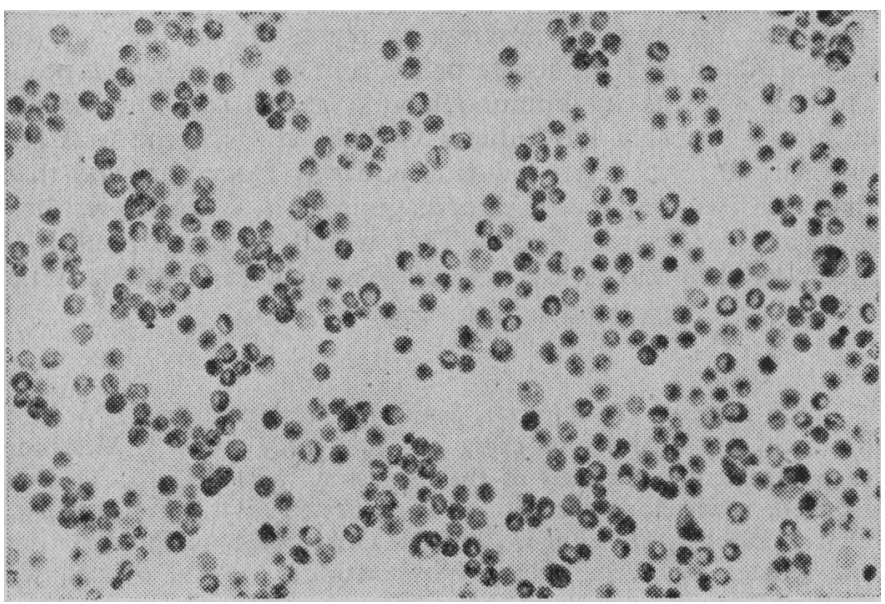

Fetal erythrocytes from the cord blood of a 12-week embryo, demonstrated by the acid-elution technique. Both megaloblastic and normoblastic erythropoiesis are evident. $(\times 280$.

\section{Subjects Studied}

Studies of three groups of patients were made.

Group A.-This group consisted of 91 normal, pregnant women; of these, 41 were less than 16 weeks pregnant, corresponding in length of gestation to most of the abortion cases in groups $\mathrm{B}$ and $\mathrm{C}$, and 50 were more advanced in pregnancy, from 16 weeks to term (Table I).

TABle I.-Group A. Estimation of Fetal Cell Scores in Normal

\begin{tabular}{cc|c|c|c|c|c|c}
\hline & \multicolumn{6}{c|}{ Pregnancy } \\
\hline Period of Gestation & $\begin{array}{c}\text { No. } \\
\text { of } \\
\text { Cases }\end{array}$ & \multicolumn{5}{|c|}{ Fetal Cells } \\
\cline { 3 - 7 } & & 0 & 1 & $>1$ & $>5$ & Incidence \\
\hline$<16$ weeks &. & 41 & 35 & 3 & 3 & 0 & $14 \cdot 6 \%$ \\
16 to 40 weeks & $\cdots$ & 50 & 38 & 6 & 5 & 1 & $24 \cdot 0 \%$ \\
\hline
\end{tabular}

Group B.-Seventy women presented with bleeding in the early months of pregnancy, and were examined during the acute phase of bleeding before any surgery. Of these, 54 were less than 16 weeks and 16 were 16 to 20 weeks pregnant. They were further subdivided clinically into two groups, those having threatened abortions (requiring bed rest and conservative therapy) and those with inevitable or incomplete abortions (who were curetted the following day) (Table II).

TABLE II.-Group B. Estimation of Fetal Cell Score in Abortions Before Surgery

\begin{tabular}{ll|c|c|c|c|c|c}
\hline \multicolumn{2}{c|}{ Type of Abortions } & $\begin{array}{c}\text { No. } \\
\text { of } \\
\text { Cases }\end{array}$ & \multicolumn{4}{|c|}{ Fetal Cells } & Incidence \\
\cline { 3 - 7 } & & 0 & 1 & $>1$ & $>5$ & \\
\hline Threatened.. & $\cdots$ & 34 & 26 & 4 & 4 & 0 & $23.5 \%$ \\
Incomplete & $\cdots$ & 36 & 27 & 5 & 3 & 1 & $25.0 \%$
\end{tabular}

Group C.-Eighty-one patients with abortions were examined within 48 hours after curettage. Sixty-three of these women were less than 16 weeks pregnant, five were from 16 to 20 weeks pregnant, and 13 had had early abortions of unknown gestational period. Pregnancy was confirmed by macroscopic and histological examination of the curettings in all these patients. This group was further subdivided into those 55 patients who were curetted and did not receive oxytocic drugs and those 26 with minimal associated bleeding who received

${ }^{1}$ Fetal cell score is a term used by Woodrow et al. (1965) to denote the number of fetal cells counted in 50 low-power fields. oxytocic drugs routinely with curettage. These two groups were clinically comparable.

\section{Results}

Group $A$ (Table I).-The $14.6 \%$ and $24.0 \%$ incidence of fetal cells found in the maternal circulation during pregnancy of less than 16 weeks $(6 / 41)$ and of 16 weeks or more $(12 / 50)$, respectively approximates the incidence recorded by Zipursky and Israels, 1967.

Group $B$ (Table II).-There was no significant statistical increase in incidence when comparing fetal cell counts after threatened abortions $(8 / 34)$ with those after incomplete abortions (9/36). Comparison of the incidence of fetal cells during early normal pregnancy of less than 16 weeks $(6 / 41)$ with that during threatened abortion $(8 / 34)$ showed no significant statistical increase $\left(\chi^{2}=0.959, P<0.5\right)$. Frequency of fetal cells during pregnancy of less than 16 weeks $(6 / 41)$ and incomplete abortion (9/36) showed no significant statistical increase $\left(\chi^{2}=1.505, P<0 \cdot 3\right)$. Though there appears to be an increase when comparing percentages in normal pregnancies with those in threatened and incomplete abortions, these results are not statistically significant.

Group $C$ (Table III).-There is no statistically significant increase in fetal cell score in group $C 1$, with no drug administration $(25 / 55)$, compared with that in group $C 2$, which received oxytocic drugs as a routine adjunct to curettage $(13 / 26)$ $\left(\chi^{2}=1.036, P<0.5\right)$. Four patients showed more than five fetal cells, equivalent to $>0.2 \mathrm{ml}$. of fetal blood. The maximum number of fetal cells was 10 , the equivalent of 0.4 to $0.5 \mathrm{ml}$. of transfused fetal blood (Woodrow et al., 1965). Comparison of the incidence of fetal cells in incomplete abor-

TABle III.-Group C. Estimation of Fetal Cell Score After Curettage

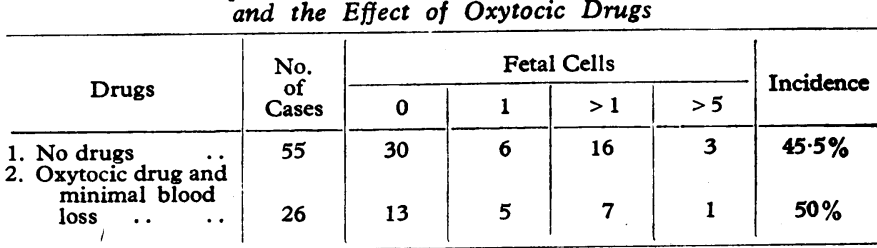

tions $(9 / 36)$, group $\mathrm{B}$, with that in the post-curettage subjects, group C $1(25 / 55)$, showed a significant increase in the frequency of fetal cells after curettage $\left(\chi^{2}=4.093, P<0.05\right)$. Curettage $(25 / 55)$ caused significant transplacental passage of fetal red cells in comparison with normal pregnancy of less than 16 weeks $(6 / 41),\left(\chi^{2}=10 \cdot 189, P<0.01\right)$.

\section{Discussion}

Levine et al. (1941) postulated that Rh-immunization was caused by the transplacental passage of fetal erythrocytes into the maternal circulation. The fetal erythrocytes carry the D antigen and promote the formation of anti-D in a D-negative mother; the antibody passes back into the fetal circulation and results in a haemolytic anaemia in a D-positive fetus. Chown (1954) originally described the presence of fetal cells in the maternal circulation. Gunson (1957) reported the formation of Rh-antibodies in the mother as the result of fetomaternal transfusion. In the early 1960s many papers appeared which substantiated the finding of fetal cells in the maternal circulation and the mechanism of Rh-sensitization (Finn et al., 1961 ; Taylor and Kullman, 1961 ; Fraser and Raper, 1962).

It is well recognized that $\mathrm{ABO}$ incompatibility protects against primary Rh-immunization (Levine, 1943). The fetal cells appear immediately after birth in most cases and disappear within 24 hours post-partum in ABO incompatible pregnancies (Fraser and Raper, 1962). In Liverpool, England, Finn et al. 
(1961) and Clarke et al. (1963) and in the U.S.A. Freda et al. (1964) showed conclusively that $\mathrm{Rh}$-disease could be prevented by passive immunization with high-titre anti-D plasma or anti$\mathrm{D}$ gammaglobulin. The $\mathrm{Rh}$-antigen is present in fetal erythrocytes of a 38-day embryo (Bergström et al., 1967), and thus abortion is a potential sensitizing methanism in $\mathrm{Rh}$-incompatible pregnancies, provided the amount of fetal blood present is sufficient to induce sensitization. Woodrow and Finn (1966) showed that the Kleihauer acid-elution fetal cell scores of 1 or 2 are associated with a considerable margin of error. In our study four of the 85 non-pregnant controls had an occasional cell containing haemoglobin $\mathrm{F}$, and therefore it may be that the incidence of feto-maternal haemorrhage in pregnancy was overestimated.

Gellén et al. (1965) demonstrated that vaginal termination of pregnancy increased the incidence of fetal cells in the maternal circulation. More recent studies by Matthews and Matthews (1969) showed that in a quarter of abortions terminated therapeutically by either the vaginal or the abdominal route evidence of feto-maternal haemorrhage was found. In only $3 \%$, however, was the amount of fetal blood above $0.2 \mathrm{ml}$., their suggested potentially immunizing dose. Our investigations confirm the studies of Matthews and Matthews (1969) that after spontaneous abortions (threatened or incomplete) the risk of transplacental haemorrhage is small. In one case of the 70 studied, however, more than five fetal cells were found, equivalent to $>0.2 \mathrm{ml}$. of fetal blood. The apparent increase suggested by the percentages is not statistically significant, and was probably due to the few patients who were admitted with self-inflicted drug or instrumental interference with their pregnancy. There is, however, a definite, statistically significant increase in the incidence of fetal cells noted after therapeutic curettage for incomplete abortion.

The combined use of oxytocic drugs and curettage therapy did not show a statistical increase in the frequency of fetal cells when compared with the group treated by curettage alone. The conclusion was that both curettage and curettage combined with oxytocic drugs promoted an increase in feto-maternal haemorrhage.

The dose of fetal blood required to induce a primary immunization response was shown by Zipursky et al. (1963b) to be $1.3 \mathrm{ml}$. It was demonstrated experimentally that repeated doses of $0.5 \mathrm{ml}$. in $\mathrm{Rh}$-negative volunteers did not induce primary immunization, though as little as $0.1 \mathrm{ml}$. of fetal $\mathrm{Rh}-$ positive blood was capable of promoting a secondary or "booster" response to preformed antibody. Contrary to this study, Woodrow and Donohoe (1968) quoted experimental data by Zipursky et al. (1965), who were able to immunize Rh-negative volunteers with repeated injections of $0.1 \mathrm{ml}$. of $\mathrm{Rh}$-positive blood. The highest fetal score found after abortion was 10 , equivalent to 0.4 to $0: 5 \mathrm{ml}$. of fetal blood. Four of the 81 post-abortion cases had a fetal cell score of $>5$ (greater than $0.2 \mathrm{ml}$. of fetal blood). Woodrow and Donohoe (1968) reported that abortions occurring between the first and second completed pregnancies did not result in a rise in antibody titre during the second pregnancy; however, only two cases of definite abortion and a third suspected abortion were cited. Preliminary studies were made in $15 \mathrm{Rh}$-negative patients of groups $B$ and $C$ three and six months after abortion; in only one, a para-1 gravida-7, was an anti-D titre of $1 / 12$ found (Katz and Zoutendyk, 1968).
The variability of reports on what constitutes a primary immunizing dose, coupled with our present low incidence of immunized $\mathrm{Rh}$-negative subjects, suggests that thempeutic curettage after abortion probably gives rise to "booster" antibody responses and not to primary immunization. Investigations are, however, in progress to try to detect the state of sensibilization or lymphocyte priming in the Rh-negative postabortion patients by immunoglobulin assays and lymphocyte culture. Probably the indirect Coombs and enzyme tests are too insensitive to detect low-titre antibody formation, and that the small feto-maternal haemorrhages may in fact have resulted in primary immunization. This would mean that all $\mathrm{Rh}$ incompatible patients after curettage should have prophylactic anti-D gammaglobulin administered.

I wish to thank the Director, South African Institute for Medical Research, for facilities to carry out this study; Dr. J. Metz for encouragement and review of the manuscript; Professor L. G. Van Dongen, newly appointed professor of obstetrics and gynaecology ; Drs. J. Blecher, D. Lithgow, and H. Glietenberg, of the obstetrics and gynaecology department, Witwatersrand Medical School, for their obstetric advice and permission to study patients under their care at the Queen Victoria Maternity Hospital; and Miss R. Israelstam for technical assistance.

\section{REFERENCES}

Bergström, H., Nilsson, L. A., Nillsson, L., and Ryttinger, L. (1967). American Fournal of Obstetrics and Gynaecology, 99, 130.

British Medical fournal, 1968, 4, 135.

Chown, B. (1954). Lancet, 1, 1213.

Clarke, C. A., et al. (1963). British Medical Fournal, 1, 979.

Cohen, F., and Zuelzer, W. W. (1964). Vox Sanguinis, 9, 75.

Dacie, J. V., and Lewis, S. M. (1966). Practical Haematology. London, Churchill.

Finn, R., et al. (1961). British Medical fournal, 1, 1486.

Fraser, I. D., and Raper, A. B. (1962). British Medical fournal, 2, 303.

Freda, V. J., Gorman, J. G., and Pollack, W. (1964). Transfusion, 4, 26.

Gellén, J., Kovács, Z., Szontágh, F. E., and Boda, D. (1965). British Medical fournal, 2, 1471.

Gunson, H. H. (1957). Pediatrics, $20,3$.

Katz, J., and Zoutendyk, A. (1968). Unpublished observations.

Kleihauer, E., Braun, H., and Betke, K. (1957). Klinische Wochenschrift, 35, 637.

Levine, P. (1943). Fournal of Heredity, 34, 71.

Levine, P., Katzin, E. M., and Burnham, L. (1941). Fournal of the American Medical Association 116, 825.

Matthews, C. D., and Matthews, A. E. B. (1969). Lancet, 1, 694.

Rosenfield, R. E. (1968). Transfusion, 8, 125.

Taylor, W. C., and Kullman, G. (1961). Fournal of Obstetrics and Gynaecology of the British Commonwealth, 68, 261.

Woodrow, J. C., and Donohoe, W. T. A. (1968). British Medical fournal, 4, 139.

Woodrow, J. C., and Finn, R. (1966). British fournal of Haematology, 12,297

Woodrow, J. C., et al. (1965). British Medical fournal, 1, 279.

Zipursky, A., Hull, A., White, F. D., and Israels, L. G. (1959). Lancet, $1,451$.

Zipursky, A., and Israels, L. G. (1967). Canadian Medical Association fournal, 97, 1245.

Zipursky, A., Pollock, J., Chown, B., and Israels, L. G. (1965). In Birth Defects. Original Article Series, vol. 1, p. 84, edited by D. Bergsma. New York.

Zipursky, A., Pollock, J., Neelands, P., Chown, B., and Israels, L. G. (1963a). Lancet, 2, 493.

Zipursky, A., Pollock, J., Neelands, P., Chown, B., and Israels, L. G. '1963b). Lancet, 2, 489. 